\begin{tabular}{|l|l|r|}
\hline A1 Fitrah & $\begin{array}{r}\text { Peningkatan Kemampuan Sosial Anak } \\
\text { Usia Dini Melalui Permainan Gelas } \\
\text { Bocor } \\
\text { Journal Of Early Childhood Islamic Education } \\
\text { ISSN }: \text { 2599-2287 E-ISSN }: \text { 2622-335X } \\
\text { Vol.2 No.2 Januari 2019 }\end{array}$ \\
\hline
\end{tabular}

\title{
PENINGKATAN KEMAMPUAN SOSIAL ANAK USIA DINI MELALUI PERMAINAN GELAS BOCOR
}

\begin{abstract}
Abstrak
Penelitian ini bertujuan untuk mengetahui kemampuan sosial anak di RA Al-Amin Cirebon, mengetahui peningkatan kemampuan sosial dengan permainan gelas bocor. Penelitian ini menggunakan metode penelitian tindakan kelas yang terdiri dari 20 anak. Data yang diperoleh dari penelitian pra siklus, siklus I, siklus II. Hasil penelitian ini memaparkan bahwa peningkatan kemampuan sosial anak melalui permainan gelas bocor pada kelompok A di RA Al-Amin Cirebon pada sebelum diberi tindakan atau Pra Siklus presentasenya adalah 40 $\%$, pada Siklus I presentasenya adalah $55 \%$, sedangkan pada siklus II presentasenya adalah $80 \%$, Jadi dapat disimpulkan bahwa presentase antara Pra Siklus ke Siklus I yaitu $15 \%$, sehingga selisih antara presentase Siklus I ke Siklus II yaitu $25 \%$.
\end{abstract}

\section{Kata kunci: kemampuan sosial, permainan gelas bocor}

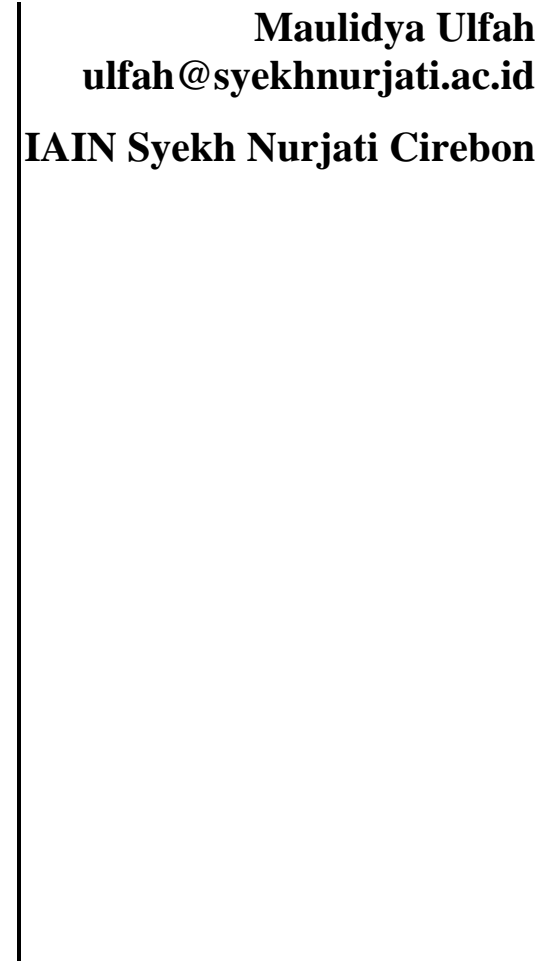

\section{PENDAHULUAN}

Kemampuan sosial adalah kemampuan anak ketika berinteraksi dan dengan orang lain sesuai peran dalam struktur sosial. (Ahamad Susanto, 2011:142). Jadi Setiap individu memiliki kemampuan sejak ia lahir, sehingga kemampuan yang anak miliki dapat menyesuaikan diri dalam sebuah lingkungan, sehingga anak dapat orangtua dapat mengembangkan kemampuan yang dimiliki oleh anak melalui pendidikan sejak dini.

Pentingnya pendidikan sejak dini memiliki tujuan agar anak didik mampu beradaptasi dengan lingkungan baru seperti lingkungan sekolah, lingkungan keluarga dan lingkungan sekitar. Sehingga anak didik mampu menyesuaikan diri dengan lingkungan baru, misalnya anak didik mampu berbagi mainan yang dimilikinya kepada temannya. Adapun firman Allah dalam surat Al-Maidah ayat 2 yang berbunyi, sebagai berikut:

"Dan tolong-menolonglah kamu dalam (mengerjakan) kebajikan dan takwa, dan jangan tolong-menolong dalam berbuat dosa dan pelanggaran. Dan bertakwalah kamu kepada Allah, Sesungguhnya Allah amat berat siksaNya" (QS. Al-Maidah:2). 


\begin{tabular}{|l|l|r|}
\hline & Al Fitrah & Peningkatan Kemampuan Sosial Anak \\
Usia Dini Melalui Permainan Gelas & Bocor \\
Journal Of Early Childhood Islamic Education & Maulidya Ulfah \\
\hline ISSN : 2599-2287 E-ISSN : 2622-335X & Mand \\
\hline
\end{tabular}

Ayat diatas menjelaskan bahwa sebagai mahluk sosial harus bisa menyesuaikan diri dengan lingkungan, selain itu juga harus tolong-menolong kepada seseorang yang membutuhkan pertolongan.

Peraturan Menteri Pendidikan dan Kebudayaan Nomor 137 Tahun 2014 (2014:63) menyatakan bahwa perkembangan sosial adalah anak didik yang memilki perilaku hidup sehat, rasa ingin tahu, kreatif dan estetis, percaya diri, disiplin, mandiri, peduli, mampu bekerja sama, mampu menyesuaikan diri, jujur dan santun dalam berinteraksi dengan keluarga, pendidik dan/atau pengasuh dan teman.

Pada usia 4-5 tahun, pola pertemanan dan hubungan yang dijalin anak didik dengan orang lain semakin stabil. Anak didik mulai memahami adanya aturan tidak hanya ketika bermain, ketika berperilaku di sekolah atau tepatnya Taman Kanak-Kanak, anak akan mulai menunjukkan perilaku yang dapat diterima oleh orangtua dan pendidik PAUD nya. (Ilman Saputra dan Alzena Masykori, 2011:9).

Identifikasi masalah dalam penelitian ini di RA Al-Amin Cirebon diantaranya yaitu anak didik belum percaya diri menjadi pemimpin dalam kelompok, anak didik tidak mampu bergabung menjadi anggota kelompok, anak didik tidak mampu mentaati aturan yang berlaku dalam suatu permainan, anak didik tidak mampu berbagi mainan yang dimilikinya kepada temannya, anak didik tidak mau menunggu giliran ketika bermain, tidak adanya permainan air, serta ada beberapa anak didik sulit untuk menyesuaikan diri dengan lingkungan baru. Berdasarkan latar belakang masalah diatas, maka peneliti tertarik untuk melakukan penelitian dengan judul Peningkatan Kemampuan Sosial Melalui Gelas Bocor pada Kelompok A di Raudhotul Athfal AlAmin Cirebon.

Permainan yang dipilih dalam penelitian ini adalah permainan yang bahan medianya adalah gelas dan ember, media tersebut mudah ditemukan disekitar kita, sehingga kita bisa memanfaatkan dari bahan bekas. Berdasarkan pemaparan latar belakang di atas maka tujuan penelitian untuk meningkatkan kemampuan sosial anak melalui permainan gelas bocor dan mengetahui bahwa permainan gelas bocor dapat meningkatkan kemampuan sosial anak pada kelompok A di RA Al-Amin Cirebon.

\section{KAJIAN TEORITIK}

\section{Konsep Perkembangan Sosial Anak Usia Dini}

Perkembangan sosial adalah
tahapan kemampuan anak dalam
berperilaku sesuai dengan harapan




\begin{tabular}{|l|l|r|}
\hline Al Fitrah & $\begin{array}{r}\text { Peningkatan Kemampuan Sosial Anak } \\
\text { Usia Dini Melalui Permainan Gelas } \\
\text { Bocor } \\
\text { Journal Of Early Childhood Islamic Education } \\
\text { ISSN }: \text { 2599-2287 E-ISSN : 2622-335X }\end{array}$ \\
Vol.2 No.2 Januari 2019 & Maulidya Ulfah \\
\hline
\end{tabular}

lingkungan

(Hurlock,1986:38).

Kemampuan anak menyesuaikan diri dalam lingkungan Taman Kanak-Kanak, memerlukan tiga proses yaitu: 1) Belajar berperilaku yang dapat diterima secara sosial, 2) Memainkan peran sosial yang dapat diterima, 3) Perkembangan sosial untuk bergaul dengan baik. Perkembangan sosial berarti perolehan kemampuan berperilaku yang sesuai dengan tuntutan sosial (Hurlock, 1978:250).

\section{Dalam Peraturan Menteri}

Pendidikan dan Kebudayaan Nomor 137

Tahun 2014 (2014:63) menyatakan bahwa perkembangan sosial adalah anak didik yang memilki perilaku hidup sehat, rasa ingin tahu, kreatif dan estetis, percaya diri, disiplin, mandiri, peduli, mampu bekerja sama, mampu menyesuaikan diri, jujur dan santun dalam berinteraksi dengan keluarga, pendidik dan atau pengasuh dan teman.

Pola perkembangan sosial anak didik usia dini mempunyai nilai ilmiah dari nilai praktis. Pertama, pengetahuan tentang pola perkembangan akan membantu para psikolog perkembangan untuk mengetahui apa yang diharapkan anak didik, pada anak usia berapa suatu perilaku diharapkan muncul dan kapan pola yang lebih matang menggantikan pola sebelumnya. Jika orang tua terlalu banyak mengharapkan munculnya perilaku pada masa perkembangan tertentu padahal anak didik tidak mampu, perasaan ini akan membahayakan perkembangan anak didik (Maulidya ulfah. 2013:45-46).

Pada anak usia dini, standar tingkat pencapaian perkembangan anak usia dini tentang lingkup perkembangan sosial, diantaranya: 1) Dapat berinteraksi dengan teman sebaya dan orang dewasa, 2) Dapat menjaga keamananan diri sendiri, 3) Menunjukkan rasa percaya diri, 4) Dapat menunjukkan kemandirian, 5) Mulai menunjukkan sikap kedisiplinan.

\section{Standar Tingkat Pencapaian} Perkembangan tentang kemampuan Sosial

Pada Anak Usia 4-5 tahun pola pertemanan dan hubungan yang dijalin anak didik dengan orang lain juga semakin stabil. Anak didik mulai memahami adanya aturan tidak hanya ketika bermain, ketika anak memahami aturan di Taman Kanak-Kanak, anak juga mampu memahami aturan dirumah, serta anak akan mulai menunjukkan perilaku yang dapat diterima oleh orangtua dan pendidik PAUD nya (Ilman Saputra, 2011:9). 


\begin{tabular}{|l|l|r|}
\hline Al Fitrah & $\begin{array}{r}\text { Peningkatan Kemampuan Sosial Anak } \\
\text { Usia Dini Melalui Permainan Gelas } \\
\text { Bocor } \\
\text { Journal Of Early Childhood Islamic Education } \\
\text { ISSN : 2599-2287 E-ISSN : 2622-335X }\end{array}$ \\
\hline & Maulidya Ulfah \\
\hline
\end{tabular}

\section{Menurut PERMENDIKBUD}

Nomor 137 Tahun 2014 pada Standar Tingkat Pencapaian Perkembangan Anak tentang Lingkup Perkembangan Sosial Pada Anak Usia 4-5 Tahun diantaranya anak didik mampu menunjukkan sikap mandiri dalam memilih kegiatan, memahami peraturan dan disiplin, menjaga diri sendiri dari lingkungannya, menghargai keunggulan orang lain, mau berbagi, menolong dan membantu teman, mentaati aturan yang berlaku dalam suatu permainan, menghargai orang lain dan mengenal lingkungan sosial (keluarga, teman, tempat tinggal, tempat ibadah, budaya, transportasi).

Jadi dapat disimpulkan bahwa kegiatan yang dilakukan anak didik ketika dalam lingkungan sekolah akan berpengaruh positif dalam tumbuh kembang anak didik, agar anak didik menjadi pribadi yang lebih baik dan mampu menghargai orang lain, misalnya penerapan permainan gelas bocor pada kelompok A di Raudhotul Athfal AlAmin Cirebon, permainan tersebut memiliki manfaat yaitu agar anak didik yang pasif menjadi aktif, agar anak didik ikut berinteraksi dengan teman sebayanya, anak didik mampu mentaati aturan yang berlaku dalam suatu permainan dan anak didik mampu menghargai keunggulan orang lain ketika dalam permainan ada yang kalah dan menang. Sehingga ketika anak didik bermain anak didik akan merasakan senang, tidak bosan, dan menyenangkan.

3. Peningkatan Kemampuan Sosial Anak

\section{Usia Dini}

Kemampuan sosial adalah kemampuan anak ketika berinteraksi dan dengan orang lain sesuai peran dalam struktur sosial. (Ahamad Susanto, 2011:142). Dapat disimpulkan bahwa kemampuan sosial adalah kemampuan anak didik dalam lingkungan sosialnya. Lingkungan sosial tersebut diantaranya lingkungan sekolah, lingkungan rumah atau keluarga, dan lingkungan sekitarnya seperti teman, tetangga dan masyarakat.

Berikut adalah kemampuan sosial yang perlu dimiliki oleh anak usia dini di Taman Kanak-Kanak, yaitu: kemampuan dalam menjalin hubungan dengan orang lain, kemampuan melakukan kegiatan bermain dan menggunakan waktu luang dan kemampuan anak mengatasi situasi sosial yang dihadapi.

\section{Permainan gelas bocor}

Permainan anak didik kecil bersifat spontan dan informal. Mereka bermain kapan saja dengan mainan apa saja yang mereka sukai, tanpa 


\begin{tabular}{|l|l|r|}
\hline Al Fitrah & $\begin{array}{r}\text { Peningkatan Kemampuan Sosial Anak } \\
\text { Usia Dini Melalui Permainan Gelas } \\
\text { Jocor } \\
\text { Journal Of Early Childhood Islamic Education } \\
\text { ISSN : 2599-2287 E-ISSN : 2622-335X }\end{array}$ \\
Vol.2 No.2 Januari 2019 & Maulidya Ulfah \\
\hline
\end{tabular}

memperhatikan waktu dan tempat. Mereka tidak membutuhkan peralatan pakaian khusus untuk bermain. Secara bertahap bermain menjadi semakin formal. Sebagai contoh pada tahap usia gang, anak merasa perlu adanya pakan, peralatan dan tempat khusus untuk bermain (Satrock, John W. 2007:288).

\section{Menurut Hurlock (1978:320)} menyatakan bahwa bermain adalah setiap kegiatan yang dilakukan untuk kesenangan yang ditimbulkannya, tanpa mempertimbangkan hasil akhir. Bermain dilakukan secara sukarela dan tidak ada paksaan atau tekanan dari luar atau kewajiban. Sedangkan menurut Piaget dan Hurlock menjelaskan bahwa bermain terdiri atas tanggapan yang diulang sekedar untuk kesenangan fungsional.

Adapun langkah-langkah dalam permainan gelas bocor, sebagai berikut: Alat bantu yang disediakan adalah gelas air mineral, ember berisi air. Sedangkan cara bermain dengan tahapan 1) Permainan ini bisa dilakukan di dalam (indoor) dan luar sekolah (outdoor), 2) Siapkan semua alat bantu yang dibutuhkan dalam permainan ini (gelas, ember dan air), 3) Mengambil gelas kemudian memberi lubang kecil-kecil pada bagian bawahnya (Budi Raharjo,
2015:130), 4) Jika sudah selesai, maka guru akan menjelaskan permainan yang akan dimainkan, yaitu mengambil air dengan gelas tersebut dan menuangkannya ke dalam botol dalam waktu yang sudah ditentukan, 5) Sebelum permainan dimulai guru memberikan contoh telebih dahulu agar anak tidak bingung 6) Kemudian, menententukan waktu yang harus diisi, misalnya 20 detik. Berikan waktu agar anak didik dapat cepat menyelesaikan permainan dengan kompak, 7) Sesuai aba-aba, minta anak didik untuk mengambil air dari ember dengan gelas bocor tersebut kemudian berlari ke arah botol dan menuangkannya ke dalam botol tersebut, 8) Apabila waktu sudah habis, maka lihat berapa banyak air yang berhasil dikumpulkan oleh anak didik didik, 9) Berikan apresiasi sedikit apapun air yang berhasil dituangkannya ke dalam botol. Permainan gelas bocor dilaksanakan dengan cara bermain berkelompok.

Adapun Manfaat Permainan Gelas Bocor, yaitu 1) Melatih ketangkasan anak didik, melatih ketangkasan ketika anak didik mengisi air dan berlari ke arah ember, yang dilakukan secara bergantian, 2) Melatih motorik kasar anak didik, anak didik berlari dari start 


\begin{tabular}{|l|l|r|}
\hline Al Fitrah & Peningkatan Kemampuan Sosial Anak \\
Usia Dini Melalui Permainan Gelas & Bocor \\
\hline & Journal Of Early Childhood Islamic Education & Maulidya Ulfah \\
\hline
\end{tabular}

hingga berlari ke arah ember dan dilakukan secara bergantian (Budi Raharjo, 2015:131), 3) Melatih anak didik agar selalu berusaha keras ketika melakukan sesuatu, agar anak didik dapat menyelesaikan permainan dengan waktu yang ditentukan, 4) Melatih anak agar mampu menghargai keunggulan orang lain, misalnya dalam sebuah lomba ada yang menang anak mampu menghargai kelompok tersebut, 5) Mampu mentaati aturan yang berlaku dalam suatu permainan, 6) Melatih kerja sama dalam tim atau kelompok, agar anak didik dapat berkerja sama dengan baik, 7) Mampu menyesuaikan diri terhadap lingkungan disekitar, anak didik dibagi dalam kelompok dan mampu menyesuaikan diri dengan teman satu kelompoknya.

\section{METODOLOGI}

Jenis penelitian yang dilakukan oleh peneliti menggunakan Penelitian Tindakan Kelas (PTK), yaitu suatu pencermatan terhadap kegiatan belajar berupa sebuah tindakan, yang sengaja dimunculkan dan terjadi dalam sebuah kelas secara bersama. Penelitian tersebut diberikan oleh guru dan arahan dari guru yang diberikan kepada anak didik (Arikunto Suharsimi, 2012:4).

Model Penelitian Tindakan Kelas (PTK) menurut Kemmis dan Taggart
(1998) terdiri dari 4 komponen antara lain: perencanaan (planning), Penelitian(acting), pengamatan (observing) dan refleksi (reflecting) (Sumadayo samsu, 2013:40).

Adapun tahap penelitian menurut model Kemmis dan Taggart dapat diantaranya sebagai berikut: Pertama Perencanaan (planning), yaitu dalam tahap perencanaan ini disusun mencakup semua langkah Penelitian secara rinci mulai dari Rencana Pelaksanaan Pembelajaran Harian (RPPH) sesuai tema dalam Program Semester, menyiapkan media pembelajaran, menyimpan lembar observasi untuk anak didik dan observasi penilaian pengamatan peneliti yang diamati oleh teman sejawat.

Pelaksanaan Penelitian (acting) pada tahap ini merupakan tahap implementasi (pelaksanaan) dari semua rencana yang dibuat. Langkah-langkah yang telah dilakukan adalah hasil realisasi dari perencanaan yang dibuat dan disiapkan sebelumnya, dalam pelaksanaan pembelajaran ini dibagi tiga tahap kegiatan yaitu: kegiatan awal, kegiatan inti dan kegiatan akhir, yang bertujuan untuk meningkatkan efektivitas pengembangan (Sumadayo samsu, 2013:40).

Pengamatan (observing) yaitu kegiatan observasi dilaksanak didikan dengan bersamaan dengan pelaksanaan penelitian tindakan kelas. Observasi ini 


\begin{tabular}{|l|l|r|}
\hline A1 Fitrah & $\begin{array}{r}\text { Peningkatan Kemampuan Sosial Anak } \\
\text { Usia Dini Melalui Permainan Gelas } \\
\text { Bocor } \\
\text { Journal Of Early Childhood Islamic Education } \\
\text { ISSN }: \text { 2599-2287 E-ISSN }: \text { 2622-335X } \\
\text { Vol.2 No.2 Januari 2019 }\end{array}$ \\
\hline
\end{tabular}

dilakukan dalam rangka mengumpul data peningkatan kemampuan sosial anak didik, dengan metode eksperimen dan berkelompok. Dalam melaksanakan observasi dan evaluasi penelitian dibantu dengan bekerjasama dengan guru dan pengamat dari luar (teman sejawat) (Sugiyono, 2010:310).

Pada kegiatan observasi ini, peneliti meneliti tentang peningkatan kemampuan sosial anak didik melalui gelas bocor. Subjek penelitian ini adalah kelompok A di Raudhotul Athfal Al-Amin Cirebon yang berjumlah 20 anak didik.

Refleksi (reflecting) Pada tahap ini dilakukan refleksi sekaligus analisis dari data-data yang telah diperoleh selama pembelajaran dan observasi, kemudian direfleksikan untuk melibatkan kelebihan dan kekurangan yang sudah dilaksanakan. Hasil refleksi ini digunakan untuk menetapkan langkah selanjutnya, atau membuat rencana penelitian sehingga dapat ditarik satu kesimpulan. Penelitian ini menggunakan dua siklus untuk melihat peningkatan kemampuan sosial anak didik melalui permainan gelas bocor pada kelompok A.

Adapun kisi-kisi Instrumen, antara lain yaitu: 1) Anak mampu menjadi pemimpin dalam kelompok, 2) Anak mau menunggu giliran ketika bermain, 3) Anak mampu bergabung menjadi anggota kelompok, 5) Anak mampu mentaati aturan yang berlaku dalam suatu permainan, 6) Anak mampu berbagi mainan yang dimilikinya, 7) Anak mampu menyesuaikan diri dengan lingkungan baru, 8) Anak mampu menjaga keamanan diri sendiri, 9) Anak mampu berinteraksi dengan teman sekelompoknya, 10) Anak mampu menghargai keunggulan orang lain, 11) Anak mampu menunjukkan disiplin dalam mengikuti kegiatan awal sampai akhir.

Dapat dijelaskan bahwa kisi-kisi instrumen dilakukan peneliti untuk meneliti aspek perkembangan yang akan diteliti, sehingga peneliti bisa menentukan jenis kriteria penilaian yang sesuai dengan kemampuannya, aspek penilaiannya diantaranya adalah Berkembang Sangat Baik (BSB) memiliki nilai atau skor 4), Berkembang Sesuai Harapan (BSH) memiliki nilai atau skor 3), Mulai Berkembang (MB) memiliki nilai atau skor 2), dan Belum Berkembang (BB) memiliki nilai atau skor 1. Aspek penilaian tersebut diteliti dan disesuaikan dengan kemampuan yang dimiliki anak didik.

Tehnik pengumpulan data Menurut Sugiono (2010:310) metode pengumpulan data yang umum digunakan dalam suatu penelitian adalah wawancara, dokumentasi dan observasi. Teknik analisis data yang 


\begin{tabular}{|l|l|r|}
\hline & Al Fitrah & $\begin{array}{r}\text { Peningkatan Kemampuan Sosial Anak } \\
\text { Usia Dini Melalui Permainan Gelas } \\
\text { Journal Of Early Childhood Islamic Education } \\
\text { ISSN }: 2599-2287 \text { E-ISSN }: 2622-335 X\end{array}$ \\
\hline & Maulidya Ulfah \\
\hline
\end{tabular}

peneliti gunakan adalah trianggulasi.

Analisis data pada penelitian tindakan kelas merupakan bukti adanya peningkatan atau perbaikan dari sebuah proses pembelajaran. Hasil yang diperoleh, didapat dari data selama observasi penelitian. Adapun ketuntasan atau indikator keberhasilan dalam peningkatan kemampuan sosial masing-masing anak didik jika mendapatkan nilai minimal 75\%, sedangkan ketuntasan kelas minimal $75 \%$ (Mulyasa, 2012: 183). Menurut Mulyasa terdapat rumus untuk menghitung ketuntasan individu dan ketuntasan klasikal, yaitu sebagai berikut:

a. Ketuntasan individu dengan rumus

$$
\mathrm{S}=\frac{\mathrm{R}}{\mathrm{N}} \times 100 \%
$$

Keterangan:

$\mathrm{S}=$ Persentase Ketuntasan Individual

$\mathrm{R}=$ Skor Yang diperoleh

$\mathrm{N}=$ Skor Maksimal

b. Ketuntasan Belajar Klasikal dengan

$$
\begin{gathered}
\text { rumus } \mathrm{PK}=\frac{\mathrm{JT}}{\mathrm{JS}} \text { X } 100 \% \\
\mathrm{PK}=\text { Persentase Ketuntasan Klasikal } \\
\mathrm{JT}=\text { Jumlah Anak didik yang Tuntas } \\
\text { JS }=\text { Jumlah Seluruh Anak didik }
\end{gathered}
$$

\section{A. HASIL DAN PEMBAHASAN}

\section{Pra Siklus}

Pada kegiatan hasil pra siklus bahwa anak didik yang tuntas 8 anak didik atau sekitar $40 \%$, sedangkan anak didik yang belum tuntas dalam permainan gelas bocor ada 12 anak didik, yaitu sekitar 60 \%. Hasil refleksi menunjukkan bahwa tingkat kecapaian ketuntasan individu dan kalasikal masih kurang, sehingga dibutuhkan pengulangan permainan gelas bocor pada siklus ke I.

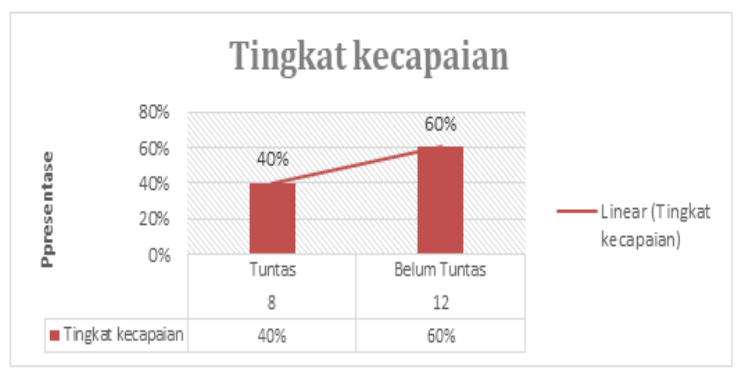

\section{Diagram 1 \\ Diagram Penilaian Pra Siklus}

\section{Siklus I}

Pada kegiatan hasil siklus I bahwa anak didik yang tuntas 11 anak didik atau sekitar $55 \%$, sedangkan anak didik yang belum tuntas dalam permainan gelas bocor ada 9 anak didik, yaitu sekitar 45 $\%$. Sehingga pencapaian pada siklus I masih belum memenuhi ketuntasan klasikal dan peneliti melakukan pengulangan pada siklus ke II. 


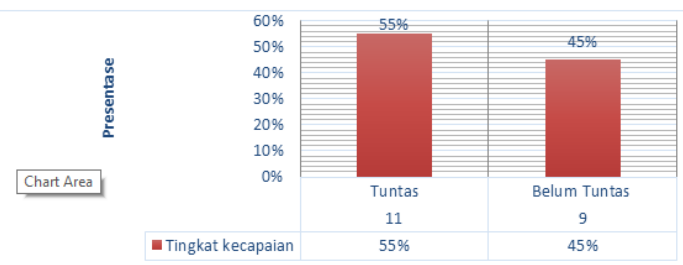

Diagram 2

Diagram Penilaian kegiatan siklus I

\section{Siklus II}

Pada kegiatan siklus II ketuntasan secara individual dan klasikal sudah tuntas yakni anak didik atau sekitar $80 \%$, sedangkan

anak didik yang belum tuntas ada 4 anak didik atau sekitar $20 \%$.

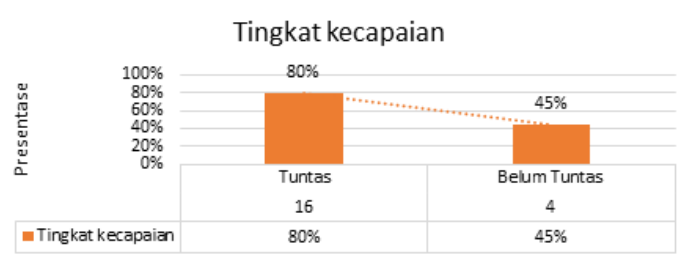

Diagram 3

Diagram Penilaian Kegiatan Siklus II

4. Perbedaan peningkatan Kemampuan Sosial Melalui Permainan Gelas Bocor pada Kegiatan Pra Siklus, Siklus I dan Siklus II.

Tabel 1

Hasil Siklus Peningkatan Kemampuan Sosial melalui Permaianan Gelas Bocor

\begin{tabular}{|r|r|r|r|r|}
\hline No & Nama Anak & Pra Siklus & Siklus I & Siklus II \\
\hline $\mathbf{1}$ & HA & $55 \%$ & $55 \%$ & $62,5 \%$ \\
\hline $\mathbf{2}$ & AA & $55 \%$ & $80 \%$ & $80 \%$ \\
\hline $\mathbf{3}$ & ZT & $57,5 \%$ & $80 \%$ & $62,5 \%$ \\
\hline $\mathbf{4}$ & NL & $60 \%$ & $82,5 \%$ & $82,5 \%$ \\
\hline $\mathbf{5}$ & DWA & $75 \%$ & $55 \%$ & $87,5 \%$ \\
\hline $\mathbf{6}$ & IA & $60 \%$ & $57,5 \%$ & $80 \%$ \\
\hline $\mathbf{7}$ & AA & $77,5 \%$ & $80 \%$ & $80 \%$ \\
\hline $\mathbf{8}$ & RD & $80 \%$ & $85 \%$ & $82,5 \%$ \\
\hline $\mathbf{9}$ & FRR & $60 \%$ & $82,5 \%$ & $82,5 \%$ \\
\hline $\mathbf{1 0}$ & TA & $82,5 \%$ & $87,5 \%$ & $87,5 \%$ \\
\hline $\mathbf{1 1}$ & BG & $82,5 \%$ & $60 \%$ & $80 \%$ \\
\hline $\mathbf{1 2}$ & HF & $60 \%$ & $52,5 \%$ & $82,5 \%$ \\
\hline $\mathbf{1 3}$ & MA & $55 \%$ & $80 \%$ & $87,5 \%$ \\
\hline $\mathbf{1 4}$ & MNA & $92,5 \%$ & $90 \%$ & $95 \%$ \\
\hline $\mathbf{1 5}$ & GS & $55 \%$ & $57,5 \%$ & $52,5 \%$ \\
\hline
\end{tabular}




\begin{tabular}{|c|c|c|}
\hline & $\begin{array}{l}\text { Al Fitrah } \\
\text { Journal Of Early Childhood Islamic Education } \\
\text { ISSN : } 2599-2287 \text { E-ISSN : 2622-335X } \\
\text { Vol.2 No.2 Januari } 2019\end{array}$ & $\begin{array}{r}\text { Peningkatan Kemampuan Sosial Anak } \\
\text { Usia Dini Melalui Permainan Gelas } \\
\text { Bocor } \\
\text { Maulidya Ulfah }\end{array}$ \\
\hline
\end{tabular}

\begin{tabular}{|c|c|c|c|c|}
\hline 16 & MIM & $50 \%$ & $52,5 \%$ & $80 \%$ \\
\hline 17 & MR & $55 \%$ & $55 \%$ & $55 \%$ \\
\hline 18 & SN & $90 \%$ & $80 \%$ & $80 \%$ \\
\hline 19 & NA & $85 \%$ & $52,5 \%$ & $85 \%$ \\
\hline 20 & RN & $50 \%$ & $92,5 \%$ & $85 \%$ \\
\hline & Total & $\begin{array}{c}1325 \%: 20 \\
=66,25 \%\end{array}$ & $\begin{array}{c}1467,5 \%: 20 \\
=73,4 \%\end{array}$ & $\begin{array}{l}1614,5 \%: 20 \\
=80,783 \%\end{array}$ \\
\hline & Keterangan & Pra Siklus & Siklus I & Siklus II \\
\hline & $\begin{array}{r}\text { Anak Yang } \\
\text { Tuntas }\end{array}$ & $\begin{array}{c}8 \text { Anak } \\
(40 \%)\end{array}$ & $\begin{array}{l}11 \text { Anak } \\
(55 \%)\end{array}$ & $\begin{array}{c}16 \text { Anak } \\
(80 \%)\end{array}$ \\
\hline & $\begin{array}{l}\text { Anak yang } \\
\text { elum Tuntas }\end{array}$ & $\begin{array}{c}12 \text { Anak } \\
(60 \%)\end{array}$ & $\begin{array}{l}8 \text { Anak } \\
(45 \%)\end{array}$ & $\begin{array}{l}4 \text { Anak } \\
(20 \%)\end{array}$ \\
\hline
\end{tabular}

Dapat disimpulkan

berdasarkan tabel di atas bahwa sebelum melaksanakan atau pra siklus, maka peneliti mengenalkan media terlebih dahulu, seperti ada gelas dan ember. Setelah kegiatan anak didik pada sebelum Penelitian atau pra siklus presentasenya adalah (40\% adalah 8 anak didik tuntas dan 12 anak didik belum tuntas atau 60\%). Pada kegiatan Siklus I presentasenya adalah ( $55 \%$ adalah 11 anak didik yang tuntas dan anak didik yang tidak tuntas 9 anak didik atau sekitar $45 \%$ ), sehingga presentase kenaikan antara pra siklus dan siklus I ( siklus 55\%-pra siklus $40 \%$ ) adalah $15 \%$.

Peneliti melakukan pengulangan pada siklus II yang tingkat pencapaiaannya adalah
(80\%, anak didik yang tuntas 16 anak didik, sedangkan anak didik yang tidak tuntas 4 anak didik atau sekitar $20 \%$ ). Jadi dapat disimpulkan bahwa kenaikan presentase antara Siklus I dan Siklus II ( Siklus II 80\%-Siklus I $55 \%) 25 \%$. Adapun peningkatan yang diperoleh anak pada permainan gelas bocor mulai dari sebelum tindakan atau pra siklus, siklus I dan siklus II dapat dilihat pada tabel dibawah ini:

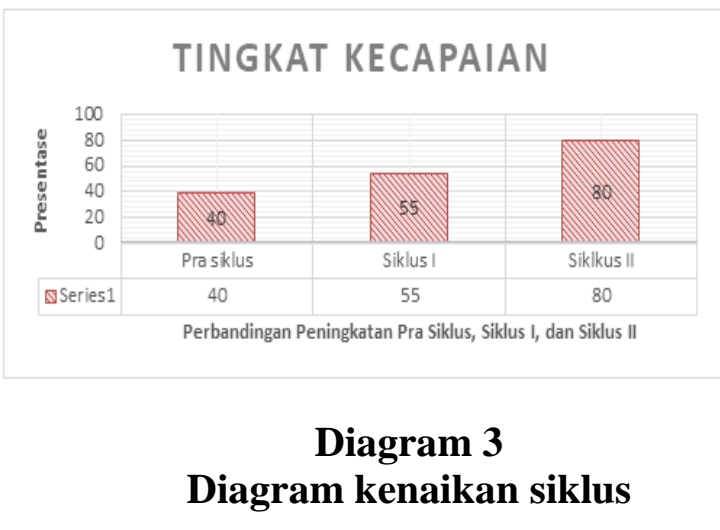




\begin{tabular}{|l|l|r|}
\hline A1 Fitrah & $\begin{array}{r}\text { Peningkatan Kemampuan Sosial Anak } \\
\text { Usia Dini Melalui Permainan Gelas } \\
\text { Bocor } \\
\text { Journal Of Early Childhood Islamic Education } \\
\text { ISSN }: \text { 2599-2287 E-ISSN }: \text { 2622-335X } \\
\text { Vol.2 No.2 Januari 2019 }\end{array}$ \\
\hline
\end{tabular}

\section{SIMPULAN}

Penelitian ini mengahsilkan hal-hal sebagai berikut, diantaranya peningkatan kemampuan sosial melalui permainan gelas bocor pada kelompok A di Raudhotul Athfal Al-Amin Cirebon sebelum tindakan atau pada pra siklus kurang maksimal, sebab adanya anak didik yang mengikuti permainan akan tetapi masih dibantu oleh ibunya. Sedangkan pada kegiatan siklus I anak didik yang pendiam dan sebelumnya masih dibantu oleh bu guru, pada siklus I anak didik tersebut memiliki kemampuan dalam beradaptasi dengan kelompoknya. Pada kegiatan siklus II mengalami peningkatan, sebab media gelas bocor diberikan kertas kado agar permainannya menarik, setelah itu sebelum melakukan permainan anak didik menyanyikan lagu terlebih dahulu, agar anak didik memiliki perasaan senang ketika bermain dengan kelompoknya. Selain itu permainan gelas bocor ini memiliki tujuan agar anak didik mampu bekerja sama dengan kelompoknya, anak didik mampu mengikuti aturan permainan, anak didik mampu menyesuaikan diri menjadi anggota kelompok dan lain-lain.

Penerapan permainan yang dilaksanakan di Raudhotul Athfal Al-Amin Cirebon, menghasilkan data penilaian dari pra siklus, siklus I dan sikus II tidak lepas dari bantuan guru dan teman sejawat. Bahan permainan gelas bocor sangat mudah ditemukan disekitar lingkungan diantaranya adalah gelas, ember dan air. Sehingga permainan gelas bocor dapat bermanfaat bagi guru dan sekolah juga bermanfaat bagi tumbuh-kembang anak didik serta dapat meningatkan mutu pembelajaran.

Peningkatan kemampuan sosial anak didik melalui permainan gelas bocor pada kelompok A di Raudhotul Athfal Al-Amin Cirebon, pada kegiatan pra siklus presentasenya adalah $40 \%$ (8 anak didik tuntas dan 12 anak didik belum tuntas atau 60\%). Pada kegiatan Siklus I presentasenya 55\% (11 anak didik yang tuntas atau 55\%, sedangkan anak didik yang tidak tuntas 9 anak didik atau sekitar $45 \%$ ), sehingga peningkatan sesudah pra siklus yaitu $15 \%$. Peneliti melakukan pengulangan pada siklus II, sehingga tingkat pencapaiaannya $80 \%$ (16 anak didik anak didik yang tuntas $80 \%$, sedangkan 4 anak didik yang tidak tuntas atau sekitar $20 \%$ ). Jadi dapat disimpulkan bahwa kenaikan dari siklus I yaitu $55 \%$ dan Siklus II yaitu $80 \%$, yaitu $25 \%$ dan sudah memenuhi ketuntasan minimal indikator keberhasilan dalam penelitian. 


\begin{tabular}{|l|l|r|}
\hline Al Fitrah & Peningkatan Kemampuan Sosial Anak \\
Usia Dini Melalui Permainan Gelas & Bocor \\
\hline & Journal Of Early Childhood Islamic Education & Maulidya Ulfah \\
\hline
\end{tabular}

\section{DAFTAR PUSTAKA}

Arikunto Suharsimi dkk. 2006. Penelitian Penelitian Kelas. Jakarta:Bumi Aksara.

Diwatika, 2008. Tinjauan Tentang Sosialisasi Dengan Taman Sebaya Dalam Perkembangan Sosialnya Di Taman Kanak-Kanak Peritwi 1 Kantor Gubernur Padang.01469/2008.

Daroah, 2013. Meningkatan Kemampuan Bahasa Melalui Metode Bercerita Dengan Media Audio Visual Di Kelompok B1 RAUDHOTUL ATHFAL Perwanida 02 Slawi. 1601910029.

Hurlock, B. Elizabeth. 1978. Perkembangan Anak didik. Jakarta: Erlangga.

Iva Noorlaila. 2010. Panduan Lengkap Mengajar PAUD. Yogyakarta:Pinus Book Publisher.

Ilman Saputra dan Alena Masykouri, 2011. Membangun Sosial-Emosi di Usia 4-6 Tahun. Jakarta:Dirjen PAUDNI.

KEMENDIKBUD. Undang-Undang Sistem Pendidikan Nasional (2013). Indonesia.

KEMENDIKBUD. (2015c). Pedoman Pengembangan Tema Pembelajaran Pendidikan Anak Usia Dini. Jakarta: Kementrian Pendidikan dan Kebudayaan.

Kementrian Pendidikan dan Kebudayaan Nomor 137 Tahun 2014 tentang Kurikulum Pendidikan Anak Usia Dini.

Kumia, Yaya. 2016. Modul Guru Pembelajaran Taman Kanak-Kanak Kelompok Kompetensi G. Bandung.

Ulfah, Maulidya. 2018. Pengaruh Penggunaan Strategi Pembelajaran
Inquiry terhadap Kecerdasan

Naturalis Anak Usia Dini di Kabupaten Majalengka. Jurnal Al Athfal Jurnal Pendidikan Anak. DOI: http://dx.doi.org/10.14421/alathfal.2018.41-03. http://ejournal.uinsuka.ac.id/tarbiyah/index.php/alathfal/ article/view/41-03

Ulfah, Maulidya. 2018. PENINGKATAN KEMAMPUAN KOMUNIKASI MELALUI PERMAINAN MEMASANGKAN GAMBAR DENGAN KATA DI TAMAN KANAK-KANAK CIREBON. Jurnal Awlady: Jurnal Pendidikan anak. DOI: http://dx.doi.org/10.24235/awla dy.v4i1.2656.

http://www.syekhnurjati.ac.id/jurnal/i ndex.php/awlady/article/view/2656

Mayke S. Tedjasaputra. 2001. Bermain,Mainan,dan Permainan untuk Pendidikan Usia Dini. Jakarta: Graha media.

Misbahuddin. 2013. Analisis Data penelitian dengan Statistik, Jakarta: Bumi Aksara.

Muniningrum, Ratnawati. (2012). Pengembangan Sosial Emosional, Bandung: Pusat Pengembangan dan Pemberdayaan Pendidik dan Tenaga Kependidikan Bidang Taman KanakKanak dan Pendidikan Luar Biasa.

Mulyasa, 2012. Praktek Penelitian Tindakan Kelas. Bandung: Remaja Rosdakarya.

Nugraha, Ali. 2006. Metode Pengembangan Sosial Emosional. Jakarta: Universitas Terbuka.

Raharjo, budi. 2015. Seabrek Game Kreatif Pegangan Ayah-Bunda. Yogyakarta: DIVA Prees. 


\begin{tabular}{|c|c|c|}
\hline & $\begin{array}{l}\text { Al Fitrah } \\
\text { Journal Of Early Childhood Islamic Education } \\
\text { ISSN : } 2599-2287 \text { E-ISSN : 2622-335X } \\
\text { Vol.2 No.2 Januari } 2019\end{array}$ & $\begin{array}{r}\text { Peningkatan Kemampuan Sosial Anak } \\
\text { Usia Dini Melalui Permainan Gelas } \\
\text { Bocor } \\
\text { Maulidya Ulfah }\end{array}$ \\
\hline
\end{tabular}

Rini Desmareaza, 2012. Peningkatan Perkembangan Sosial Emosional Anak Melalui Permainan Montase Di RAUDHOTUL ATHFAL Darul 'Ulum PGAI PADANG.50991/2009.

Satrock, John W. 2007. Perkembangan Anak didik. Jakarta: Erlangga

Sugiyono, 2010. Metodologi Penelitian Kuantitatif Kualitatif Dan $R \& D$. Bandung: ALFABETA.

Susanto, Ahmad. 2011. Perkembangan Anak Usia Dini. Jakarta: Kencana Prenada Media Group.

Suyadi, Maulidya Ulfah. (2015). Konsep Dasar PAUD, Bandung: PT Remaja Rosdakarya

Wahyudin, uyu dan Mubiar Agustin. 2011. Penilaian Perkembangan Anak Usia Dini:Panduan Guru, Tutor, Fasilitator Dan Pengelola Pendidikan Anak Usia Dini. Bandung:PT Refika Aditama. 